\title{
Perineal ulcer: a rare cause of extensive subcutaneous emphysema
}

\author{
Kamal Kant Sahu, ${ }^{\circledR}$ Akil Adrian Sherif, Ajay Kumar Mishra, Sunita Vyas, \\ Susan V George
}

Department of Internal Medicine, Saint Vincent Hospital, Worcester, MA, USA

\section{Correspondence to \\ Dr Kamal Kant Sahu,} drkksahu85@gmail.com

Accepted 21 March 2019

\section{DESCRIPTION}

A 90-year-old man with a past medical history of hypertension, coronary artery disease and stage IV chronic kidney disease was referred from a nursing home for poor oral intake and weakness of one week duration. Examination suggested diffuse crepitations on palpation of his chest, back and pelvic region. There was no recent history of surgical intervention, diagnostic instrumentation, fall or penetrating trauma. Physical examination showed an ulcer at the base of the scrotum of approximately $3 \times 3 \mathrm{~cm}$ in dimension (figure $1 \mathrm{~A}$ ). Inspection showed healthy margins without any pus discharge or surrounding cellulitis. X-ray of the chest showed extensive chest wall subcutaneous emphysema (SE) predominantly involving the left lateral chest wall extending into the abdomen (figure 1B). CT of chest/abdomen/pelvis delineated extensive SE extending from the perineum up to the cervical region (figure 1C,D). Air track lines were appreciated along the subcutaneous tissues of the chest (figure $2 \mathrm{~A}, \mathrm{~B}$ ) and abdominal wall with the involvement of the perineum, surrounding the penis and bilateral testicles (figure 2C), the left pectoral and paraspinal musculature, neck up to the C7 level. A final diagnosis of extensive SE secondary to perianal ulcer was made.

$\mathrm{SE}$, as the name suggests, is situated under the skin and is easily appreciated on clinical examination on palpation. Crepitus is appreciated over the skin as a fine crackly feeling akin to 'popping' of

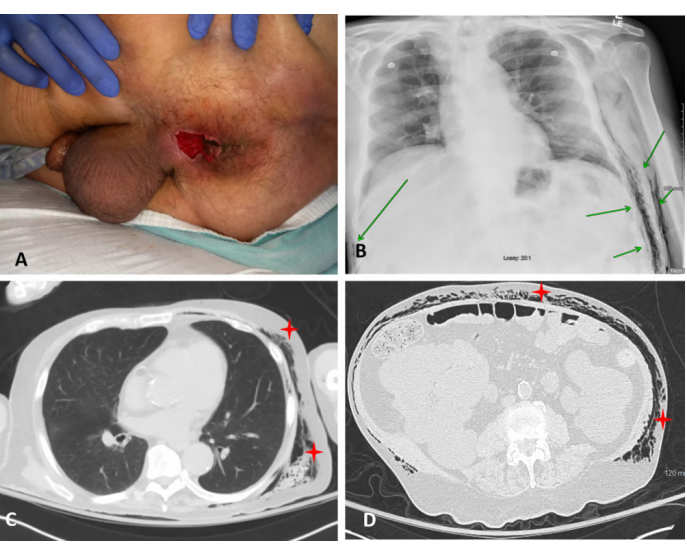

Figure 1 (A) Clinical image of perineum showing large ulcer. (B) Chest $\mathrm{X}$-ray showing extensive subcutaneous emphysema on both sides. (C,D) CT transverse view of chest (C) and abdomen (D) showing air pockets in the chest and abdominal wall predominantly involving the left side.

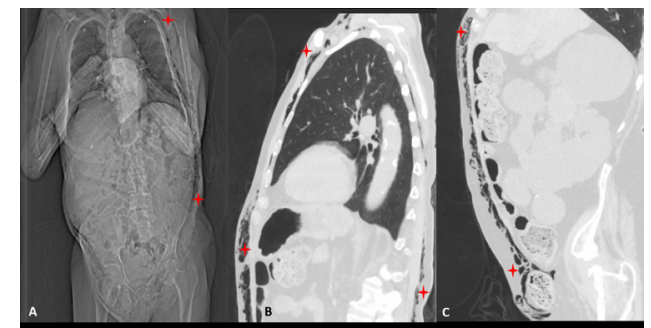

Figure 2 (A) CT skiagram confirming the extensive soft tissue gas collection from the perineum up to the cervical region. (B) CT chest sagittal view showing predominant involvement of the left side. (C) CT abdomen/pelvis sagittal view showing involvement of the perineum surrounding air pockets around the penis and bilateral testicles.

several tiny bubbles. ${ }^{1}$ Common differentials include Boerhaave's syndrome, alveolar rupture, necrotising fasciitis and communicating fistulas. ${ }^{23}$ Clinical diagnosis with physical examination is the most common modality of diagnosis. However, SE may also be visualised easily on imaging as collections of air densities within tissue structures. Investigating the patient for perforated bowel or a fulminant soft tissue infection would be of paramount importance as while SE itself remains generally benign, some of the causal aetiologies maybe life threatening requiring rapid intervention. Complications arising from compression of sensitive structures around an enlarging SE include compartment syndrome which requires urgent decompression. Rarely, injury to surrounding vascular structures may also result in an air embolism. ${ }^{45}$

Conservative management resulting in spontaneous resolution through reabsorption is generally the norm while approaching SE in the absence of acute complications. However, the involvement of structures such as the mediastinum or a resultant compartment syndrome may necessitate more aggressive approaches such as fine-needle aspiration, emergent mediastinotomy, surgical drains and sterile surgical 'blowhole' incisions that will allow for decompression. Negative pressure wound therapy may be combined with such interventions for severe cases. A final resort would be exploratory surgical decompression, although this is associated with increased mortality. In emergency room, in addition to clinical examination, imaging studies play a pivitol role in evaluation of disease extension in many similar situations. ${ }^{67}$ 


\section{Learning points}

Presence of subcutaneous emphysema (SE) should always prompt diligent search for the potential source of air leak.

- While SE is most often benign, a clinical finding of SE must always prompt a workup of the common differentials that are potentially life threatening.

Contributors KKS: management and writing of the manuscript. AS: management and literature search. AKM: photography, follow-up of the patient and editing. SV: management, editing and follow-up. SVG: manuscript literature search, crucial comments and editing.

Funding The authors have not declared a specific grant for this research from any funding agency in the public, commercial or not-for-profit sectors.

Competing interests None declared.

Patient consent for publication Obtained.
Provenance and peer review Not commissioned; externally peer reviewed.

\section{REFERENCES}

1 Ziment I. History of the treatment of chronic bronchitis. Respiration 1991;58:37-42.

2 Maunder RJ, Pierson DJ, Hudson LD. Subcutaneous and mediastinal emphysema. Pathophysiology, diagnosis, and management. Arch Intern Med 1984;144:1447-53.

3 Schumann R, Polaner DM. Massive subcutaneous emphysema and sudden airway compromise after postoperative vomiting. Anesth Analg 1999:89:796.

4 Blumberg N, LaTOWSKY LW, Embolism CA. Subcutaneous emphysema, and spontaneous pneumothorax in a tuberculous patient: report of an unusual case. Dis Chest 1940:6:211-4.

5 Joannides M, Tsoulos GD. The etiology of interstitial and mediastinal emphysema: (Experimental production of air embolism, acute pneumothorax, acute pneumoperitoneum, interstitial, mediastinal and retroperitoneal emphysema). Arch Surg 1930;21:333-9.

6 Sahu KK, Sherif AA, Lopez CA. Omega sign: Radiological appearance of sigmoid volvulus. J Med Imaging Radiat Oncol 2019:63:82-3.

7 Sahu KK, Maradana S, Mishra A, et al. A spontaneous rectus sheath hematoma. Intern Emerg Med 2018;13:1341-3

Copyright 2019 BMJ Publishing Group. All rights reserved. For permission to reuse any of this content visit https://www.bmj.com/company/products-services/rights-and-licensing/permissions/

BMJ Case Report Fellows may re-use this article for personal use and teaching without any further permission.

Become a Fellow of BMJ Case Reports today and you can:

- Submit as many cases as you like

- Enjoy fast sympathetic peer review and rapid publication of accepted articles

- Access all the published articles

Re-use any of the published material for personal use and teaching without further permission

For information on Institutional Fellowships contact consortiasales@bmjgroup.com

Visit casereports.bmj.com for more articles like this and to become a Fellow 